\title{
Ovarian Non-Hodgkin's Lymphoma: A Clinicopathologic Study of Eight Primary Cases
}

Russell Vang, M.D., L. Jeffrey Medeiros, M.D., Roger A. Warnke, M.D., John P. Higgins, M.D., Michael T. Deavers, M.D.

Stanford University Medical Center (RV, RAW, JPH), Department of Pathology (Laboratory of Surgical Pathology), Stanford, California; and The University of Texas-M.D. Anderson Cancer Center (JM, MTD), Houston, Texas

Primary (localized) non-Hodgkin's lymphoma (NHL) of the ovary is rare. We studied eight cases of primary ovarian NHL to better understand the clinicopathologic and immunophenotypic features of these tumors. The patients ranged in age from 29 to 62 years (mean 47 years). Pelvic complaints were the most common symptoms; however, three of eight neoplasms were discovered incidentally. All tumors were unilateral and Ann Arbor stage $I_{\mathrm{E}}$. The three incidental NHL were microscopic (largest 1.2 $\mathrm{cm})$, whereas the grossly evident lesions ranged from 7.5 to $20 \mathrm{~cm}$ (mean 13.3). Each tumor was classified according to the World Health Organization Classification as follows: diffuse large B-cell lymphoma (three cases), follicular lymphoma (two cases), Burkitt lymphoma (one case), T-cell anaplastic large cell lymphoma (one case), and precursor T-lymphoblastic lymphoma (one case). Six tumors were of B-cell lineage, and two tumors were of T-cell lineage. All three diffuse large B-cell lymphomas were positive for BCL-6, two were positive for CD10, and two were positive for BCL-2. Estrogen and progesterone receptors were negative in all NHLs assessed. Patients were treated by various combinations of surgery, chemotherapy, and radiotherapy. Clinical follow-up ranged from 1.3 to 11.7 years (mean 5.2) and all patients were alive without disease at last follow-up. We conclude that most patients with primary ovarian NHL present with symptoms attributable to an ovarian mass, but in a subset of patients ovarian NHL may be detected incidentally. With appropriate therapy, patients appear to have a favorable prognosis although follow-up is short for some patients in this study.

Copyright $(2001$ by The United States and Canadian Academy of Pathology, Inc.

VOL. 14, NO. 11, P. 1093, 2001 Printed in the U.S.A.

Date of acceptance: July 21, 2001.

Address reprint requests to: Michael T. Deavers, M.D., The University of Texas-M.D. Anderson Cancer Center, Department of Pathology, Box 85, 1515 Holcombe Boulevard, Houston, TX 77030-4095; e-mail: mdeavers@notes.mdacc.tmc.edu.
KEY WORDS: Gynecologic, Immunohistochemistry, Lymphoma, Ovary.

Mod Pathol 2001;14(11):1093-1099

Non-Hodgkin's lymphoma (NHL) may involve the gynecologic tract, and the ovary is one of the more common anatomic sites to be involved. Ovarian involvement by NHL is usually secondary, occurring as a part of systemic disease. Localized, presumably primary, NHL of the ovary is rare (1).

Previous reports of ovarian NHL have included both primary and secondary cases. In these studies, primary NHLs of the ovary represent only a minority of the cases reported, usually less than $10 \%$. Thus, secondary cases have been well characterized in the literature $(2,3)$, but information about primary cases is limited.

Furthermore, several reported cases of primary ovarian NHL did not have adequate Ann Arbor staging information, and therefore may not have been truly localized. For these reasons, we chose to collect well-characterized cases of primary ovarian NHL to describe their clinicopathologic and immunophenotypic features.

\section{MATERIALS AND METHODS}

Cases of primary NHL of the ovary were identified from the surgical pathology files of Stanford University Medical Center and The University of Texas-M.D. Anderson Cancer Center. These cases included both in-house surgical specimens and consultation cases. We collected low-stage cases, designated as Ann Arbor stage $\mathrm{I}_{\mathrm{E}}$ after clinicopathologic staging, and considered these tumors to be primary. In contrast, we considered NHL involving the ovary as a part of Ann Arbor stage $\mathrm{III}_{\mathrm{E}}$ and IV disease to probably represent secondary involvement and excluded those cases from the study. However, we acknowledge that by using these definitions, any NHL that arose in the ovary and subsequently disseminated would be eliminated from 
our study. We did not encounter any stage $\mathrm{II}_{\mathrm{E}}$ cases. Four cases were previously reported in a clinicopathologic review of NHL involving the gynecologic tract (1), and the clinical features of three of these cases were also reported elsewhere (4).

Clinical information was obtained by review of the medical chart and correspondence with the clinician. Histologic features were studied using sections routinely stained with hematoxylin-eosin. Each neoplasm was classified according to the recently proposed World Health Organization Classification (5).

Immunohistochemical studies were performed using formalin-fixed, paraffin-embedded tissue sections and a variable panel of antibodies specific for the following antigens: CD3, CD20, CD21, CD30, CD99, BCL-2, BCL-6, and ALK-1 (DAKO, Carpinteria, CA); CD10 (Novocastra, Burlingame, CA); CD43 (Becton Dickinson, Franklin Lakes, NJ); estrogen and progesterone receptors (Ventana, Tucson, AZ); and TdT (SuperTechs, Bethesda, MD).

\section{RESULTS}

\section{Clinical Features}

Eight cases of localized ovarian NHL, all Ann Arbor stage $\mathrm{I}_{\mathrm{E}}$, were included in this study. The patients ranged in age from 29 to 62 years (mean 47 years). The most common presenting signs or symptoms were: pelvic pain $(n=2)$; pelvic mass ( $n$ $=1)$; and urinary frequency and incontinence $(n=$ 1). One patient presented with constitutional symptoms that were not otherwise specified. Three pa- tients had neoplasms that were detected as incidental findings. Two of these patients underwent total abdominal hysterectomy and bilateral salpingo-oophorectomy for uterine leiomyomas, and one patient had excision of an endometriotic cyst within which NHL was identified in the cyst wall. All of the neoplasms were unilateral; seven were right-sided and one involved the left ovary. The three incidental tumors were microscopic $(\leq 1.2 \mathrm{~cm})$, and no lesion was observed grossly. Five neoplasms were grossly identified and ranged in size from 7.5 to $20 \mathrm{~cm}$ (mean 13.3).

Treatment consisted of various combinations of surgery, chemotherapy, and radiotherapy. Seven patients were treated surgically: five underwent total abdominal hysterectomy and bilateral salpingooophorectomy, and two underwent bilateral salpingo-oophorectomy. Seven and two patients, respectively, received chemotherapy and radiotherapy. Clinical follow-up ranged from 1.3 to 11.7 years (mean 5.2 years). All patients were alive, relapsefree, and disease-free at last follow-up.

\section{Histologic and Immunohistochemical Findings (Table 1)}

[Table 1] Three tumors (Cases 3, 4, and 7) were diffuse large B-cell lymphoma (DLBCL). Two DLBCL had entirely diffuse architecture, while approximately 25 to $50 \%$ of one DLBCL (Case 7) contained follicular areas. All of the DLBCL consisted of sheets of large lymphoid cells with a moderate amount of pale cytoplasm. The nuclei were round or had ir-

TABLE 1. Primary (Stage $I_{E}$ )Non-Hodgkin's Lymphoma of the Ovary

\begin{tabular}{|c|c|c|c|c|c|c|c|c|c|c|c|c|}
\hline \multirow{2}{*}{$\begin{array}{l}\text { Case } \\
\text { No. }\end{array}$} & \multirow{2}{*}{$\begin{array}{c}\text { Age } \\
(\mathrm{y})\end{array}$} & \multirow{2}{*}{ Presentation } & \multirow{2}{*}{ Side } & \multirow{2}{*}{ Size $(\mathrm{cm})$} & \multirow{2}{*}{ Diagnosis } & \multicolumn{5}{|c|}{ Immunophenotype } & \multirow{2}{*}{ Therapy } & \multirow{2}{*}{ Follow-Up } \\
\hline & & & & & & Lineage & CD10 & CD99 & Bcl-2 & Bcl-6 & & \\
\hline 1 & 29 & Pelvic pain & $\mathrm{R}$ & 13 & T-LBL & T-cell & + & + & ND & - & $\begin{array}{l}\text { TAH-BSO, } \\
\text { CT }\end{array}$ & NED, $5.8 \mathrm{y}$ \\
\hline 2 & 39 & $\begin{array}{l}\text { Incidental } \\
\text { finding }\end{array}$ & $\mathrm{R}$ & Microscopic & ALCL & T-cell & ND & ND & ND & ND & TAH-BSO & NED, 4 y \\
\hline 3 & 41 & $\begin{array}{l}\text { Urinary } \\
\text { frequency, } \\
\text { incontinence }\end{array}$ & $\mathrm{L}$ & 18 & DLBCL & B-cell & - & - & + & + & $\begin{array}{l}\text { BSO, CT, } \\
\text { RT }\end{array}$ & NED, $5.5 \mathrm{y}$ \\
\hline 4 & 43 & Pelvic pain & $\mathrm{R}$ & 8 & DLBCL & B-cell & + & - & + & + & $\begin{array}{l}\text { TAH-BSO, } \\
\text { CT }\end{array}$ & NED, 6 y \\
\hline 5 & 50 & $\begin{array}{c}\text { Incidental } \\
\text { finding }\end{array}$ & $\mathrm{R}$ & Microscopic & $\begin{array}{l}\text { Follicular } \\
\text { lymphoma, } \\
\text { Grade } 2\end{array}$ & B-cell & + & - & - & + & $\begin{array}{l}\text { TAH-BSO, } \\
\text { CT }\end{array}$ & NED, $3.5 \mathrm{y}$ \\
\hline 6 & 51 & $\begin{array}{l}\text { Incidental } \\
\text { finding }\end{array}$ & $\mathrm{R}$ & Microscopic & $\begin{array}{l}\text { Follicular } \\
\text { lymphoma, } \\
\text { Grade } 3\end{array}$ & B-cell & + & - & - & + & $\begin{array}{l}\text { TAH-BSO, } \\
\text { CT }\end{array}$ & NED, $1.3 \mathrm{y}$ \\
\hline 7 & 59 & Pelvic mass & $\mathrm{R}$ & 7.5 & $\begin{array}{l}\text { DLBCL } \\
\text { with } \\
\text { follicular } \\
\text { areas }\end{array}$ & B-cell & + & - & - & + & BSO, CT & NED, $3.5 \mathrm{y}$ \\
\hline 8 & 62 & $\begin{array}{l}\text { Constitutional } \\
\text { symptoms, } \\
\text { NOS }\end{array}$ & $\mathrm{R}$ & 20 & $\begin{array}{l}\text { Burkitt } \\
\text { Lymphoma }\end{array}$ & B-cell & - & - & ND & + & $\mathrm{CT}, \mathrm{RT}$ & NED, $11.7 \mathrm{y}$ \\
\hline
\end{tabular}

ALCL, anaplastic large cell lymphoma; BSO, bilateral salpingo-oophorectomy; CT, chemotherapy; DLBCL, diffuse large B-cell lymphoma; ER, estrogen receptor; ND, not done; NED, no evidence of disease; NOS, not otherwise specified (detailed clinical information of presentation not available); PR, progesterone receptor; RT, radiotherapy; TAH, total abdominal hysterectomy; T-LBL, precursor T-lymphoblastic lymphoma; +, positive; -, negative. 
regular nuclear contours, irregularly distributed chromatin, nucleoli, and many mitoses (Fig. 1). The follicular areas in Case 7 were composed of cells similar to those seen in the diffuse areas of the tumor. Areas of necrosis and sclerosis were observed. All three DLBCL were positive for CD20 and BCL-6, two cases were positive for CD10, and two cases were positive for BCL-2. The DLBCL with follicular areas was negative for BCL-2.

Two cases (Cases 5 and 6) were follicular lymphomas. Case 5 was Grade 2, with a mixture of small cleaved and atypical large cells. Case 6 was Grade 3 (Fig. 2), with a predominance of large cleaved cells. Both cases were positive for CD10, CD20, and BCL-6 and negative for BCL-2. Staining for CD21 in Case 6 highlighted a network of follicular dendritic cells in follicles; the neoplastic cells were negative.

One case each was classified as Burkitt lymphoma, T-cell anaplastic large cell lymphoma (ALCL), and T-precursor lymphoblastic lymphoma (T-LBL). The Burkitt lymphoma showed a starry-sky background and was composed of a relatively monotonous population of intermediately-sized neoplastic cells. These cells had round to slightly irregular nuclear contours, an extremely high mitotic rate, and some cells had vesicular chromatin (Fig. 3, A-B). Thus, this tumor fits within the category of atypical Burkitt lymphoma (previously designated as Burkitt-like) in the WHO classification (4). This tumor was positive for CD20 and BCL- 6 but failed to stain for CD10. The T-cell ALCL was composed of sheets of large round cells with a moderate amount of amphophilic cytoplasm. The nuclei were large, ovoid, and vesicular with large nucleoli. This neoplasm was positive for CD43 and CD30, but was negative for ALK-1. The T-LBL was diffuse and composed of small cells with minimal cytoplasm that infiltrated collagen in a single file ("indian file") pattern. The nuclei were round and convoluted.

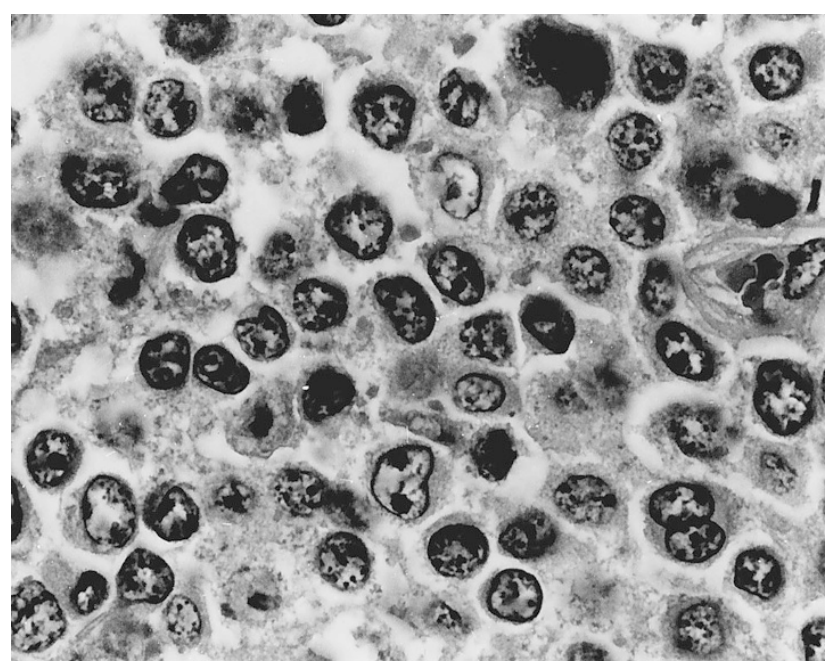

FIGURE 1. Diffuse large B-cell lymphoma (Case 4).
The chromatin was fine with inconspicuous nucleoli and mitoses were numerous (Fig. 4). The neoplastic cells were positive for CD3, CD10, CD99, and TdT and were negative for BCL- 6 .

CD99 was assessed in seven tumors, one T-LBL (discussed above) and six B-cell NHL tumors: three DLBCL, two follicular lymphomas, and one Burkitt lymphoma (Cases 3 to 8). All six B-cell neoplasms were negative for CD99. Residual ovarian stroma in the hilum and reactive small lymphocytes within the lymphomatous infiltrate, were CD99-positive. Stains for estrogen (eight cases tested) and progesterone (seven cases tested) receptors were negative in all cases assessed.

\section{DISCUSSION}

NHL uncommonly involves the gynecologic tract. However, when involved by NHL, the ovary is one of the more common anatomic sites. Previous studies of NHL involving gynecologic sites (1-3) have shown that most NHL involving the ovary are systemic tumors, of which ovarian involvement is only one aspect. Less than $10 \%$ of all ovarian NHLs reported have been localized, presumably arising in the ovary.

In the current study, we collected eight localized (Ann Arbor stage $\mathrm{I}_{\mathrm{E}}$ ) ovarian NHL, which appear to have arisen in the ovary, to further understand their clinicopathologic and immunophenotypic features. The mean age of the patients was 47 years. Patients usually sought medical attention for pelvic complaints, but in three patients the NHL was discovered as an incidental finding during the work-up of other gynecologic diseases. The incidental neoplasms were microscopic, whereas the grossly identified lesions were large, up to $20 \mathrm{~cm}$. The most common types were DLBCL (three cases) and follicular lymphoma (two cases), and six of eight NHL were of B-cell lineage. The patients were treated in various fashions and all were disease free with a mean follow-up of 5.2 years.

There is a suggestion in the literature that hormone receptors may be expressed by some hematopoietic neoplasms. Although two primary ovarian NHL studied by Monterroso et al. (2) failed to express estrogen receptors, others have shown estrogen and progesterone receptor expression in patient samples and cell lines of plasma cell myeloma, T-cell leukemia/lymphoma, acute myeloid leukemia, and B-cell chronic lymphocytic leukemia, as determined by immunocytochemical and biochemical assays (6-9). Because the NHL in our series presumably arose within the gynecologic tract, we assessed for the presence of estrogen and progesterone receptors. All cases were negative. Thus, there is no immunohistochemical support of 


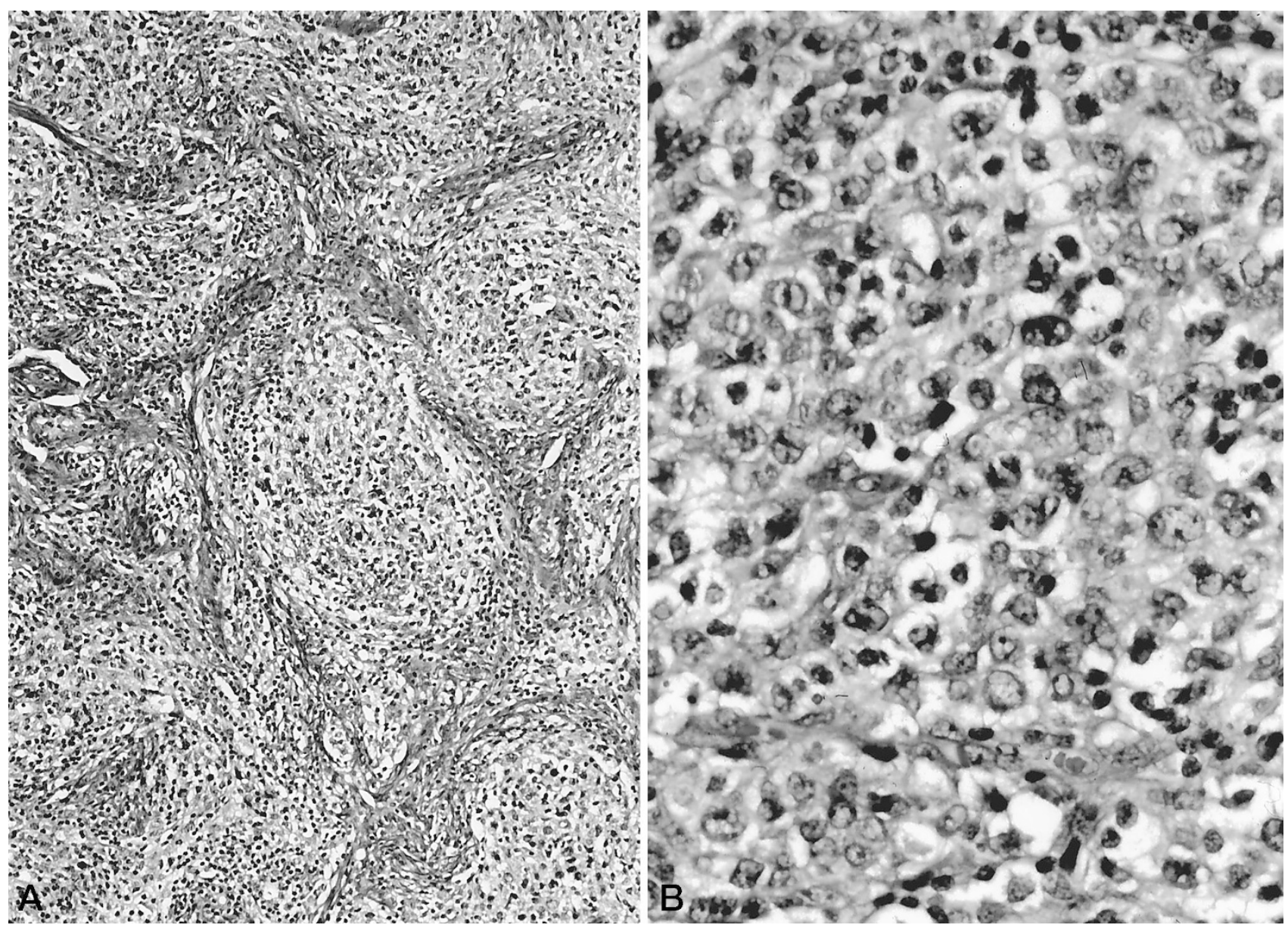

FIGURE 2. Follicular lymphoma, Grade 3. A, Follicular architecture. B, Cytologic features (Case 6).
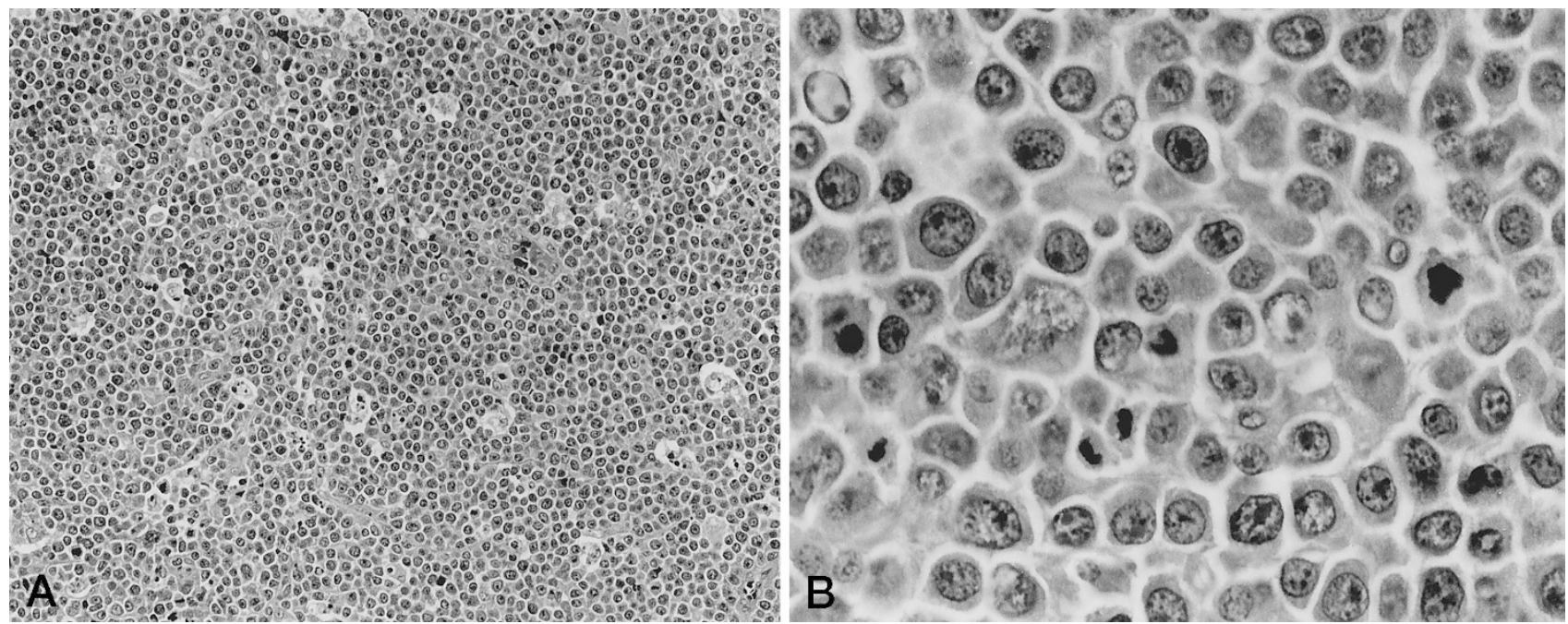

FIGURE 3. Burkitt lymphoma. A, Starry sky pattern. B, Cytologic features (Case 8).

a role for estrogen or progesterone in the pathogenesis of primary NHL of the ovary.

The histogenesis of primary ovarian NHL is perplexing. In normal ovaries, lymphocytes of B-cell and T-cell lineage are present within "cortical granulomas," and rare lymphocytes are dispersed throughout the ovarian stroma and within ovarian follicles and corpora lutea (10). We considered the possibility that chronic inflammation involving the ovaries predisposes to the development of NHL, analogous to low-grade B-cell MALT-lymphoma involving the stomach (11). However, in seven cases 


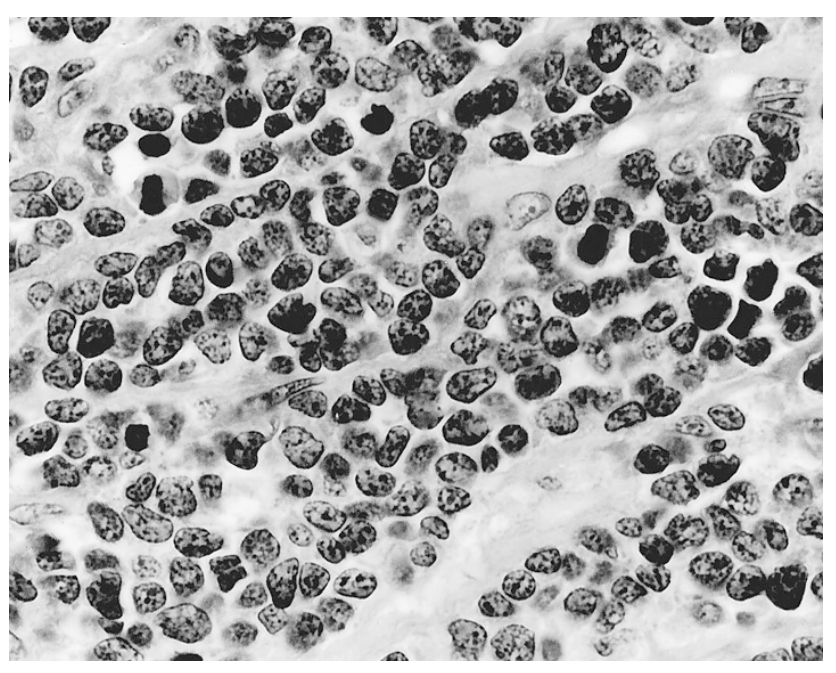

FIGURE 4. Precursor T-lymphoblastic lymphoma (Case 1).

there was no clinical or histologic evidence of inflammation. In the ALCL, a background of dispersed plasma cells and eosinophils of mild density was present within the wall of the endometriotic cyst. Thus, there is no obvious role for chronic inflammation in the pathogenesis of these tumors.

One of the findings in this series is that many cases of localized ovarian NHL are of follicle center origin. Three of eight (38\%) NHLs in this study had obvious follicular differentiation: two cases of follicular lymphoma (Cases 5 and 6) and one DLBCL with follicular areas (Case 7). Also, the results of the staining for CD10 and BCL-6 in our series may suggest follicle center derivation for primary ovarian DLBCL. All three tumors expressed CD10 and/or BCL-6. CD10 expression in non-neoplastic lymph nodes is confined predominantly to germinal centers and CD10 is also commonly expressed in follicular lymphomas $(12,13)$. Likewise, expression of BCL-6, positive in all three DLBCL in this study, is restricted to centroblasts and centrocytes of germinal centers (14), and is commonly expressed by follicular lymphomas and DLBCL of follicle center origin $(14,15)$. Thus, the presence of CD10 and/or BCL-6 expression in the DLBCL of this study supports follicle center origin, as suggested by others (12-15). The relatively high frequency of ovarian NHL of possible follicle center origin found in this study has not been previously noted in the literature (Table 2). The explanation for this is uncertain, but in most prior studies antibodies specific for CD10 and BCL- 6 that could be applied to fixed, paraffin-embedded tissue sections were not available.

Although $85 \%$ of nodal follicular lymphomas overexpress BCL-2 $(16)$ as a result of $t(14 ; 18)$, follicular lymphomas arising in extranodal sites are less often BCL-2-positive. Thus absence of BCL-2 expression, as in the follicular areas of Cases 5 to 7 in this study, may be a feature of primary follicular lymphoma of the ovary, analogous to follicular lymphomas arising in other extranodal sites (17). However, the follicular areas in our cases contained increased numbers of large cells, and it is known that BCL-2 is expressed less often in Grade 3 follicular lymphoma $(16,17)$. Alternatively, our findings could suggest that the $b c l-2$ gene does not play a role in the pathogenesis of primary ovarian follicular lymphoma. Further molecular investigation to address this possibility has not been done.

A summary of 19 cases of primary ovarian NHL (Ann Arbor stages $\mathrm{I}_{\mathrm{E}}$ or $\mathrm{II}_{\mathrm{E}}$ ) NHL $(2,18-29)$ from the literature is listed in Table 2 . Some cases originally published using FIGO staging, but for which there is insufficient information to translate into the Ann Arbor system have not been included (3). The findings in our study are somewhat comparable. The patients have a wide age range, and most patients present with pelvic or abdominal complaints. However, it is noteworthy that almost one third of cases are detected as incidental findings. The incidental neoplasms may arise in unusual settings, such as within the wall of an ovarian endometriotic cyst (Case 2 of this study), or associated with a mature cystic teratoma (20) or serous borderline tumor (26). Bilaterality is infrequent, and neoplasms may be microscopic or extremely large. DLBCL appears to be the most common type of primary ovarian NHL. This is also true for other primary NHL arising in other sites within the female genital tract (3032). Slight differences between the survival of patients in our series, $100 \%$ at 5 years, and that of patients reported in the literature, $80 \%$ at 5 years, may be due to a paucity of cases with follow-up longer than 5 years. Only one patient with primary ovarian NHL has died. However, the follow-up is relatively short for several cases in our series, as well as for those from the literature. Longer follow-up is needed to more reliably determine the long-term behavior of these lesions.

Histologically similar neoplasms that should be differentiated from NHL involving the ovary include adult granulosa cell tumor, dysgerminoma, small cell carcinoma of hypercalcemic type (33), and granulocytic sarcoma. Depending on the individual case, other less histologically problematic lesions that may be included in the differential diagnosis are poorly differentiated surface-epithelial or metastatic carcinomas, undifferentiated carcinoma (34), small cell carcinoma of pulmonary type (35), inflammatory pseudotumor, primitive neuroectodermal tumor (PNET), other non-PNET neuroectodermal tumors (36), variants of malignant mesodermal mixed tumor with scarce epithelial elements and numerous round cells, endometrioid stromal sarcoma, rhabdomyosarcoma, intraabdominal desmoplastic small round cell tumor, 


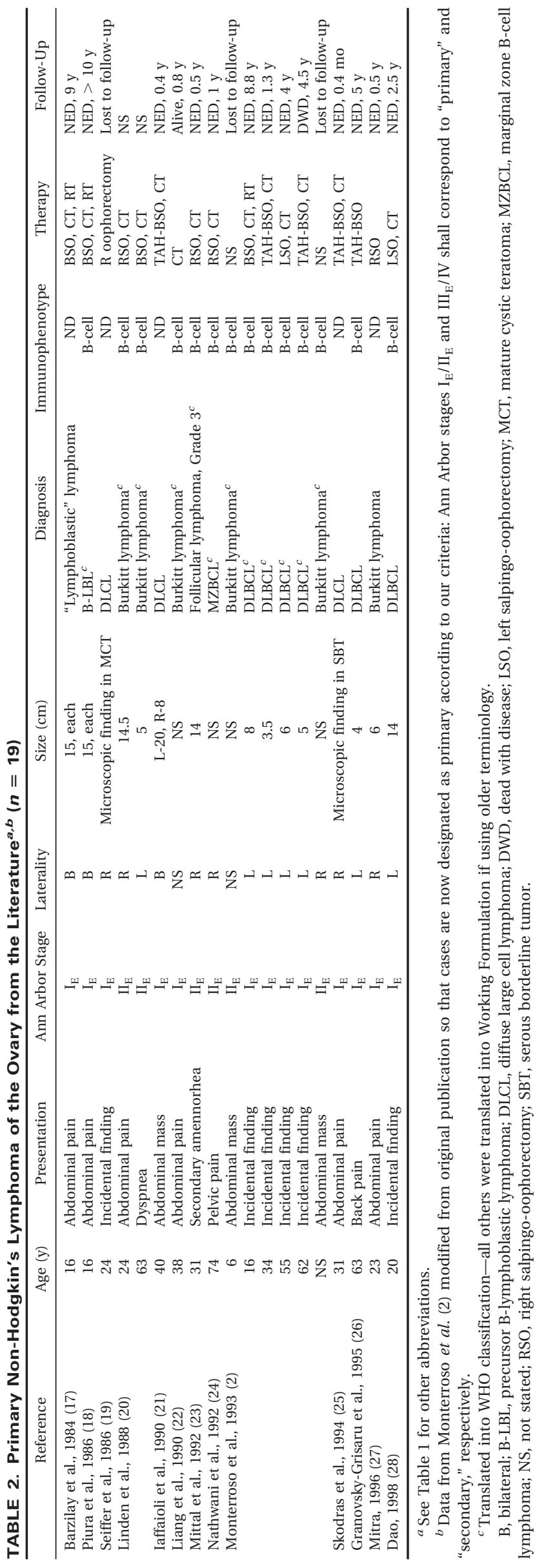

poorly-differentiated Sertoli-Leydig cell tumor (37), and melanoma. These may be distinguished from primary ovarian NHL by considering the clinical information, histologic features, and immunohistochemical profiles.

In summary, primary ovarian NHL is rare. Patients usually present because of pelvic complaints, but some cases may be detected as an incidental finding. The neoplasms may be microscopic or very large and are usually unilateral. Both B-cell and T-cell NHL can arise in the ovary, but B-cell tumors are most common, and many appear to be of follicle center origin. Patients with primary ovarian NHL appear to have a good prognosis, although the clinical follow-up in our study is relatively short.

Acknowledgments: The authors thank the following physicians for their contribution of material and/or information for this study: Alosio Graca Aranha (Rio de Janeiro, Brazil), Ierece Aymore (Rio de Janeiro, Brazil), James Breeden (Carson City, NV), Phillip Deos (Modesto, CA), Heber E. Dunaway (Metairie, LA), Larry Erickson (Modesto, CA), Jeffrey Goates (Denver, CO), Hal Levy (Denver, CO), and John Siebel (Palo Alto, CA).

\section{REFERENCES}

1. Vang R, Medeiros LJ, Fuller GN, Sarris AH, Deavers M. NonHodgkin's lymphoma involving the gynecologic tract. A review of 88 cases. Adv Anat Pathol 2001;8:200-17.

2. Monterroso V, Jaffe ES, Merino MJ, Medeiros LJ. Malignant lymphomas involving the ovary. Am J Surg Pathol 1993;17: 154-70.

3. Osborne BM, Robboy SJ. Lymphomas or leukemia presenting as ovarian tumors. An analysis of 42 cases. Cancer 1983; 52:1933-43.

4. Dimopoulos MA, Daliani D, Pugh W, Gershenson D, Cabanillas F, Sarris AH. Primary ovarian non-Hodgkin's lymphoma: outcome after treatment with combination chemotherapy. Gynecol Oncol 1997;64:446-50.

5. Harris NL, Jaffe ES, Diebold J, Flandrin G, Muller-Hermelink HK, Vardiman J, et al. The World Health Organization classification of hematological malignancies report of the Clinical Advisory Committee Meeting, Airlie House, Virginia, November 1997. Mod Pathol 2000;13:193-207.

6. Danel L, Menouni M, Cohen JH, Magaud JP, Lenoir G, Revillard JP, et al. Distribution of androgen and estrogen receptors among lymphoid and haemopoietic cell lines. Leuk Res 1985;9:1373-8.

7. Danel L, Vincent C, Rousset F, Klein B, Bataille R, Flacher M, et al. Estrogen and progesterone receptors in some human myeloma cell lines and murine hybridomas. J Steroid Biochem 1988;30:363-7.

8. Hatfill SJ, Brusnicky J, Fester E. Immunocytochemical identification of nuclear estrogen-rectors in human acute myeloid leukemia. Leuk Res 1991;15:315-20.

9. Melo N, Hobday C, Dowsett M, Catovsky D, Matutes E, Morilla R, et al. Oestrogen receptor (ER) analysis in B-cell chronic lymphocytic leukemia: correlation of biochemical and immunocytochemical methods. Leuk Res 1990;14:94952 . 
10. Suzuki T, Sasano H, Takaya R, Fukaya T, Yajima A, Date F, et al. Leukocytes in normal-cycling human ovaries: immunohistochemical distribution and characterization. Hum Reprod 1998;13:2186-91.

11. Hussell T, Isaacson PG, Crabtree JE, Spencer J. The response of cells from low-grade B-cell gastric lymphomas of mucosaassociated lymphoid tissue to Helicobacter pylori. Lancet 1993;4:571-4.

12. Dogan A, Bagdi E, Munson P, Isaacson PG. CD10 and BCL-6 expression in paraffin sections of normal lymphoid tissue and B-cell lymphomas. Am J Surg Pathol 2000;24:846-52.

13. Fang JM, Finn WG, Hussong JW, Goolsby CL, Cubbon AR, Variakojis D. CD10 antigen expression correlates with the $\mathrm{t}(14 ; 18)(\mathrm{q} 32 ; \mathrm{q} 21)$ major breakpoint region in diffuse large B-cell lymphoma. Mod Pathol 1999;12:295-300.

14. Flenghi L, Ye BH, Fizzotti M, Bigerna B, Cattoretti G, Venturi $\mathrm{S}$, et al. A specific monoclonal antibody (PG-B6) detects expression of the BCL-6 protein in germinal center B cells. Am J Pathol 1995;147:405-11.

15. Raible MD, His ED, Alkan S. Bcl-6 protein expression by follicle center lymphomas. A marker for differentiating follicle center lymphomas from other low-grade lymphoproliferative disorders. Am J Clin Pathol 1999;112:101-7.

16. Gaulard P, d'Agay MF, Peuchmaur M, Brousse N, Gisselbrecht C, Solal-Celigny $\mathrm{P}$, et al. Expression of the bcl-2 gene product in follicular lymphoma. Am J Pathol 1992;140:108995.

17. Cerroni L, Arzberger E, Putz B, Hofler G, Metze D, Sander CA, et al. Primary cutaneous follicle center cell lymphoma with follicular growth pattern. Blood 2000;95:3922-8.

18. Barzilay J, Rakowsky E, Rahima M, Yanai-Inbar I. Malignant lymphoma of the ovary: report of a case and review of the literature. Obstet Gynecol 1984;64:93S.

19. Piura B, Bar-David J, Glezerman M, Zirkin HJ. Bilateral ovarian involvement as the only manifestation of malignant lymphoma. J Surg Oncol 1986;33:126-8.

20. Seifer DB, Weiss LM, Kempson RL. Malignant lymphoma arising within thyroid tissue in a mature cystic teratoma. Cancer 1986;58:2459-61.

21. Linden MD, Tubbs RR, Fishleder AJ, Hart WR. Immunotypic and genotypic characterization of non-Hodgkin's lymphomas of the ovary. Am J Clin Pathol 1988;89:156-62.

22. Iaffaioli RV, Frasci G, Di Tuoro AS, Facchini G, Pacelli R, Scala S, et al. Malignant lymphoma of the ovary: report on two cases and review of the literature. Eur J Gynaecol Oncol 1990;11:205-8.

23. Liang R, Chiu E, Loke SL. Non-Hodgkin's lymphomas involving the female genital tract. Hematol Oncol 1990;8:295-9.
24. Mittal KR, Blechman A, Greco MA, Alfonso F, Demopoulos R. Lymphoma of ovary with stromal luteinization, presenting as secondary amenorrhea. Gynecol Oncol 1992;45:69-75.

25. Nathwani BN, Mohrmann RL, Brynes RK, Taylor CR, Hansmann ML, Sheibani K. Monocytoid B-cell lymphomas: an assessment of diagnostic criteria and a perspective on histogenesis. Hum Pathol 1992;23:1061-71.

26. Skodras G, Fields V, Kragel PJ. Ovarian lymphoma and serous carcinoma of low malignant potential arising in the same ovary. A case report with literature review of 14 primary ovarian lymphomas. Arch Pathol Lab Med 1994;118: 647-50.

27. Granovsky-Grisaru S, Beller U, Gal M, Diamant YZ, Rosenmann E. Primary lymphoma of the ovary. A case report and critical review of the literature. Eur J Gynaecol Oncol 1995; 16:392-5.

28. Mitra K. Primary lymphoma of ovary. J Ind Med Assoc 1996; 94:161.

29. Dao AH. Malignant lymphoma of the ovary: report of a case successfully managed with surgery and chemotherapy. Gynecol Oncol 1998;70:137-40.

30. Vang R, Medeiros LJ, Ha CS, Deavers M. Non-Hodgkin's lymphomas involving the uterus: a clinicopathologic analysis of 26 cases. Mod Pathol 2000;13:19-28.

31. Vang R, Medeiros LJ, Malpica A, Levenback C, Deavers M. Non-Hodgkin's lymphoma involving the vulva. Int J Gynecol Pathol 2000;19:236-42.

32. Vang R, Medeiros LJ, Silva EG, Gershenson DM, Deavers M. Non-Hodgkin's lymphoma involving the vagina: a clinicopathologic analysis of 14 patients. Am J Surg Pathol 2000;24: 719-25.

33. Young RH, Oliva E, Scully RE. Small cell carcinoma of the ovary, hypercalcemic type. A clinicopathological analysis of 150 cases. Am J Surg Pathol 1994;18:1102-16.

34. Silva EG, Tornos C, Bailey MA, Morris M. Undifferentiated carcinoma of the ovary. Arch Pathol Lab Med 1991;115:37781.

35. Eichhorn JH, Young RH, Scully RE. Primary ovarian small cell carcinoma of pulmonary type. A clinicopathologic, immunohistologic, and flow cytometric analysis of 11 cases. Am J Surg Pathol 1992;16:926-38.

36. Kleinman GM, Young RH, Scully RE. Primary neuroectodermal tumors of the ovary. A report of 25 cases. Am J Surg Pathol 1993;17:764-78.

37. Young RH, Scully RE. Ovarian Sertoli-Leydig cell tumors. A clinicopathological analysis of 207 cases. Am J Surg Pathol 1985;9:543-69. 